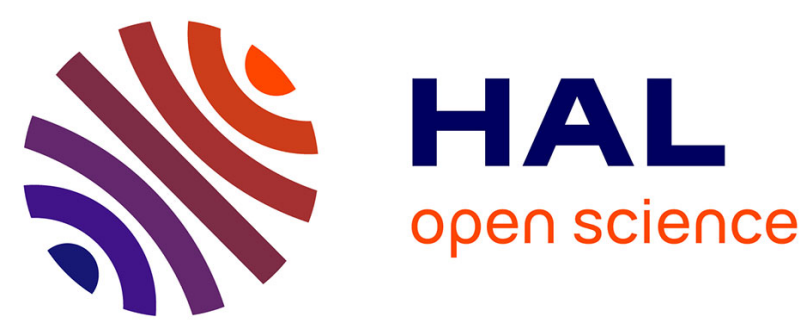

\title{
Possible role of atmosphere-biosphere interactions in triggering the last glaciation
}

Nathalie de Noblet, I. Colin Prentice, Sylvie Joussaume, Delphine Texier, Aurélie Botta, Alex Haxeltine

\section{- To cite this version:}

Nathalie de Noblet, I. Colin Prentice, Sylvie Joussaume, Delphine Texier, Aurélie Botta, et al.. Possible role of atmosphere-biosphere interactions in triggering the last glaciation. Geophysical Research Letters, 1996, 23 (22), pp.3191-3194. 10.1029/96GL03004 . hal-03334888

\section{HAL Id: hal-03334888 \\ https://hal.science/hal-03334888}

Submitted on 5 Sep 2021

HAL is a multi-disciplinary open access archive for the deposit and dissemination of scientific research documents, whether they are published or not. The documents may come from teaching and research institutions in France or abroad, or from public or private research centers.
L'archive ouverte pluridisciplinaire HAL, est destinée au dépôt et à la diffusion de documents scientifiques de niveau recherche, publiés ou non, émanant des établissements d'enseignement et de recherche français ou étrangers, des laboratoires publics ou privés. 


\title{
Possible role of atmosphere-biosphere interactions in triggering the last glaciation
}

\author{
Nathalie I. de Noblet ${ }^{1}$, I. Colin Prentice ${ }^{2}$, Sylvie Joussaume ${ }^{1,3}$, \\ Delphine Texier ${ }^{1}$, Aurélie Botta ${ }^{1}$, Alex Haxeltine ${ }^{2}$
}

\begin{abstract}
We coupled a global biome model iteratively with an atmospheric general circulation model to study the possible role of vegetation in the climate system, at the time of glacial inception 115,000 years ago. Orbital forcing alone was not sufficient to initiate glaciation when other components of the climate system were kept as present (atmospheric composition, oceans, biosphere and cryosphere). Summers were however cold enough to induce major vegetation shifts in high northern latitudes. Southward migration of the boreal forest/tundra limit helped to create favourable conditions for continental ice-sheet growth, with increasing snow depth and duration in Labrador, Arctic Canada and northern/western Fennoscandia. These results support a role for biogeophysical feedback in initiating glaciations.
\end{abstract}

\section{Introduction}

According to the Milankovitch theory [Hays et al., 1976; Berger, 1988; Imbrie et al., 1992-1993], glacial periods begin under orbital configurations when northern-hemisphere summer insolation is at a minimum. Atmospheric general circulation models (AGCMs) however do not predict the required increase in permanent snow cover at the start of the last glaciation as a consequence of orbital forcing alone [Royer et al., 1984; Rind et al., 1989; Phillipps and Held, 1994]. Positive feedbacks from other components of the climate system have been proposed, including changes in sea-surface temperatures and sea-ice distribution [Phillipps and Held, 1994; Syktus et al., 1994; Dong and Valdes, 1995; Gallimore and Kutzbach, 1995], in the thermohaline circulation [Imbrie et al., 1992-1993; Cortijo et al., 1994], and climate-induced vegetation shifts [Gallée et al., 1992]. Diagnostic calculations [Harrison et al., 1995] show vegetation changes large enough to induce further perturbations in the atmosphere [Street-Perrott et al., 1990; Foley et al., 1994; Gallimore and Kutzbach, 1996; TEMPO Members, 1996], which could in turn modify the distribution of biomes. Coupled climate/biome model experiments have already been carried out for present-day climate [Henderson-Sellers, 1993; Claussen, 1994]. Claussen and Gayler [subm.] have further applied a coupled model to the

\footnotetext{
${ }^{1}$ Laboratoire de Modélisation du Climat et de l'Environnement, CEA Saclay, Gif-sur-Yvette, France

${ }^{2}$ Global Systems Group, Department of Ecology, Lund University, Sweden

${ }^{3}$ Laboratoire d'Océanographie Dynamique et de Climatologie, CNRS/ORSTOM/UPMC, Paris, France
}

Copyright 1996 by the American Geophysical Union.

Paper number 96GL03004.

0094-8534/96/96GL-03004\$05.00 climate of the mid-Holocene and were able to simulate a large northward migration of savannas in the western Sahara, as seen in paleodata [Jolly et al., in press].

\section{Experimental set-up}

The atmospheric general circulation model (AGCM) developed at the Laboratoire de Météorologie Dynamique (version 5.3) [Sadourny and Laval, 1984; Harzallah and Sadourny, 1995] and the global biome model BIOME (version 1.0) [Prentice et. al., 1992] were coupled as in Figure 1. The AGCM includes an advanced land-surface scheme, based on SECHIBA [Ducoudré et al., 1993], but with more realistic canopy conductance and seasonal leaf area variations [Haxeltine and Prentice, 1996]. Vegetation distributions for the climate of $115 \mathrm{kyr}$ BP were based on modern climatology modified using mean monthly anomalies (departures from the control simulation) smoothly interpolated on to a $0.5^{\circ}$ grid. Each AGCM grid cell is assigned fractional covers of biomes. Fluxes are calculated separately for each biome and aggregated to provide lower boundary conditions for the AGCM.

Each AGCM simulation was 16 years long, with sea-surface temperatures and sea-ice distribution prescribed as present. Climatic variables were averaged over the last 15 years. The paleoclimate modelling intercomparison project [PMIP, Joussaume and Taylor, in press] recommends averaging over at least 10 years, and initial studies [de Noblet et al., unpublished] showed that at least $\mathbf{1 0}$ years are needed to achieve stable highlatitude biomes.

Five iterations were necessary for the atmosphere/biosphere system to reach equilibrium under $115 \mathrm{kyr}$ BP orbital conditions prescribed from Berger and Loutre [1991]. The first palaeoclimate simulation (G1) was obtained using a biome distribution based on modern climatology (long-term monthly means of temperature, precipitation and sunshine derived from Leemans and Cramer [1991]). In each subsequent iteration (G2G5) biome distribution was changed based on the mean climate from the previous iteration. Atmospheric $\mathrm{CO}_{2}$ concentration was $345 \mathrm{ppm}$ in the control simulation and $280 \mathrm{ppm}$ in the

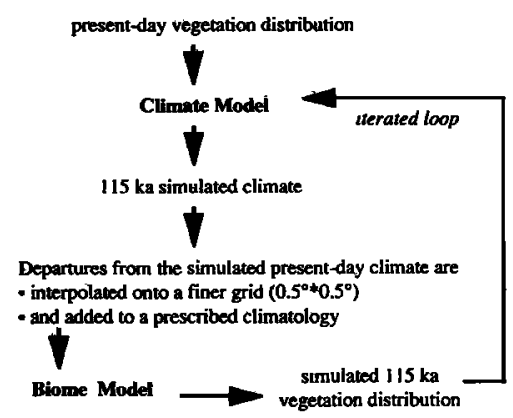

Figure 1. Schematic of the coupling between the atmospheric general circulation model and the biome model. 

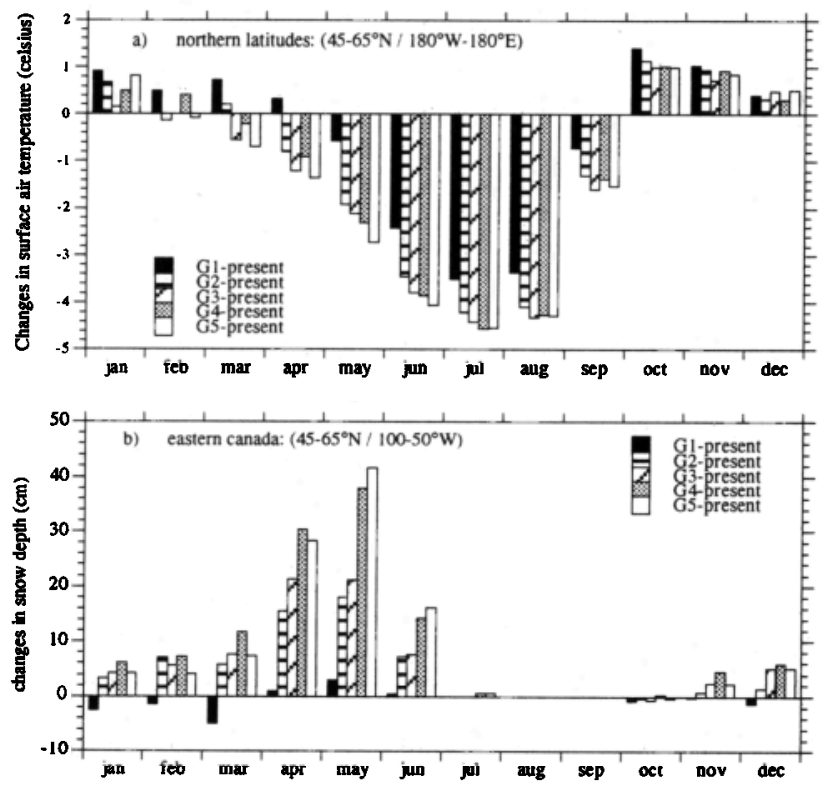

Figure 2. Simulated changes in monthly mean $a$, surface air temperatures $\left({ }^{\circ} \mathrm{C}\right)$ in the $45-65^{\circ} \mathrm{N}$ latitude band, $b$, snow depth $(\mathrm{cm})$ in eastern Canada $\left(45-65^{\circ} \mathrm{N}, 100-50^{\circ} \mathrm{W}\right)$.

palaeoclimate simulations, consistent with ice-core evidence [Barnola et al., 1987] that $\mathrm{CO}_{2}$ did not fall to glacial levels until well after $115 \mathrm{kyr}$ BP. One may argue that the $\mathrm{CO}_{2}$ level should have been set to its preindustrial value in the control simulation as well, but since sea-surface temperatures are not changed, the sensitivity of the model to lowering $\mathrm{CO}_{2}$ concentration is severely restricted [Hewitt and Mitchell, 1996]. Moreover solar forcing changes seasonally and latitudinally and vegetation changes are sensitive to changes in the seasonal cycle.

Sensitivity experiments carried out with AGCMs coupled to interactive mixed-layer ocean models [Foley et al., 1994; Dong and Valdes, 1995] have shown enhancement of orbitallyinduced climate changes when the ocean surface is set free.
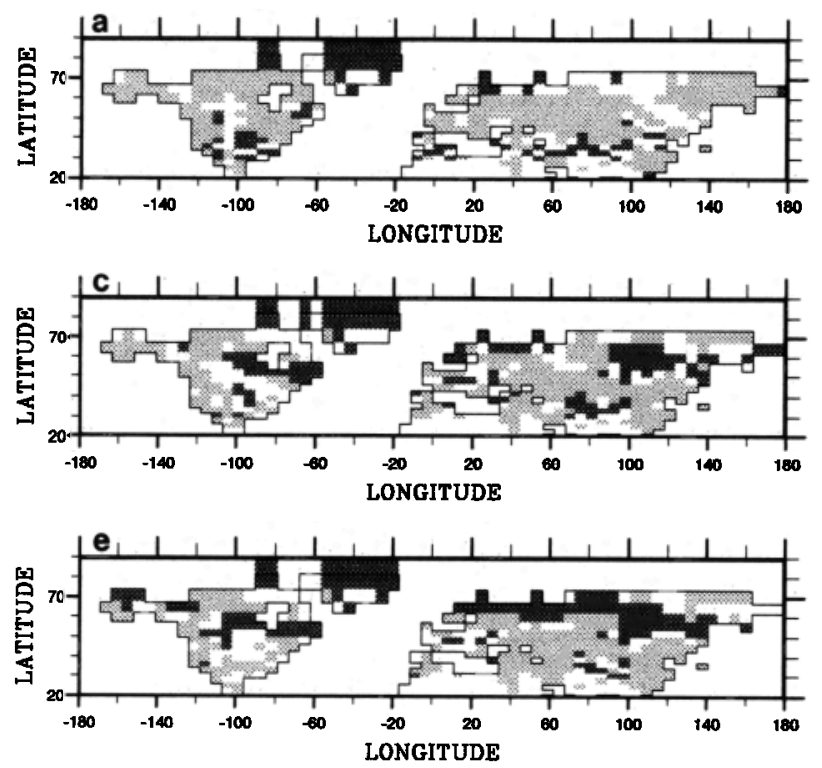

Fixed ocean surface conditions may limit the response of the simulated climate. Our goal was to isolate the sensitivity of the atmosphere. to changes in the global distribution of vegetation, while recognizing that atmosphere/ocean interaction may produce further feedbacks.

\section{Results}

Perihelion at $115 \mathrm{kyr}$ BP was in northern-hemisphere winter, as at present, while eccentricity was greater and obliquity less than present [Berger and Loutre, 1991]. Both factors imply a reduced seasonal insolation contrast in the northern hemisphere. Orbital forcing alone (simulation G1) produced conditions in the $45-65^{\circ} \mathrm{N}$ band that were cooler than present in the summer months, with maximum (3-4 K) cooling in July, but warmer than present from late autumn to early spring (Figure $2 a$ ). Snowfall and snow cover were generally less than present (Figures $3 a, 2 b$ ), due to the warm winters and springs. These results confirm that $115 \mathrm{kyr}$ BP orbital forcing of this AGCM is insufficient to start glaciation.

The cool summers simulated in G1 however produced a major change in vegetation patterns (Figures $4 a, b$ ). Present-day taiga and cold deciduous forests were replaced by tundra over large areas. These vegetation changes would raised surface albedo throughout the year and most of all during winter and spring, due to snow masking by forest [Bonan et al., 1992; Chalita and Le Treut, 1994; Foley et al., 1994]. The northern continents would therefore have absorbed considerably less solar energy than was calculated in G1, above all during spring snowmelt.

Simulation G2 shows this feedback. Simulated winter temperatures for $45-65^{\circ} \mathrm{N}$ (Figure $2 a$ ) were lower in G2 than in G1. April temperatures became lower than present, although they were warmer than present in G1. Winter snowfall remained less than present, but spring snowfall was greater and snow lasted longer (Figure $3 b$ ). Summer temperatures were further lowered and tundra extended even further south than in G1 (Figure $4 c$ ). In subsequent simulations tundra continued to expand but at a declining rate (Figure $4 d-f$ ). Mean temperatures for the summer months (Figure $2 a$ ) showed a downward trend, levelling towards G5. Winter temperatures (Figure $2 a$ ) and the
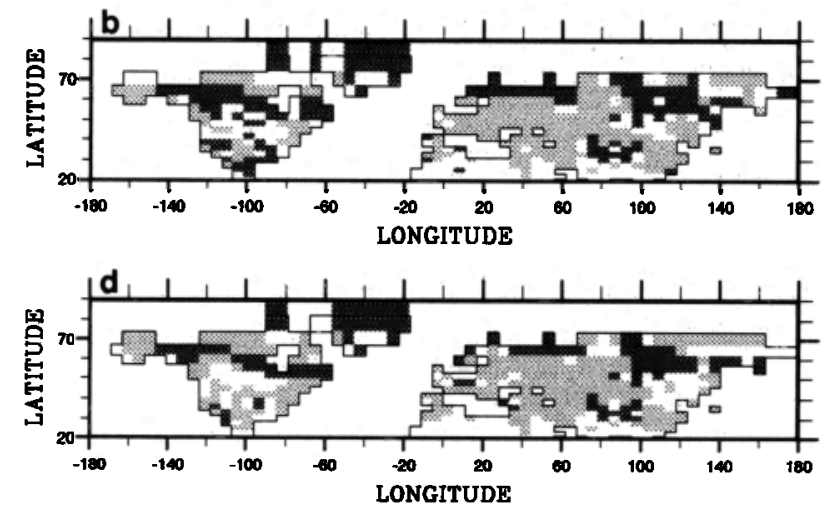

Figure 3. Simulated simultaneous changes in snow depth and duration: $a, \mathrm{G} 1$, departures from present; $b$, $\mathrm{G} 2$, departures from present; $c, \mathrm{G} 3$, departures from present; $d, \mathrm{G} 4$, departures from present; $e, \mathrm{G} 5$, departures from present. Dark shading indicates regions where both snow depth and duration increase; light shading indicates regions where they both decrease. 

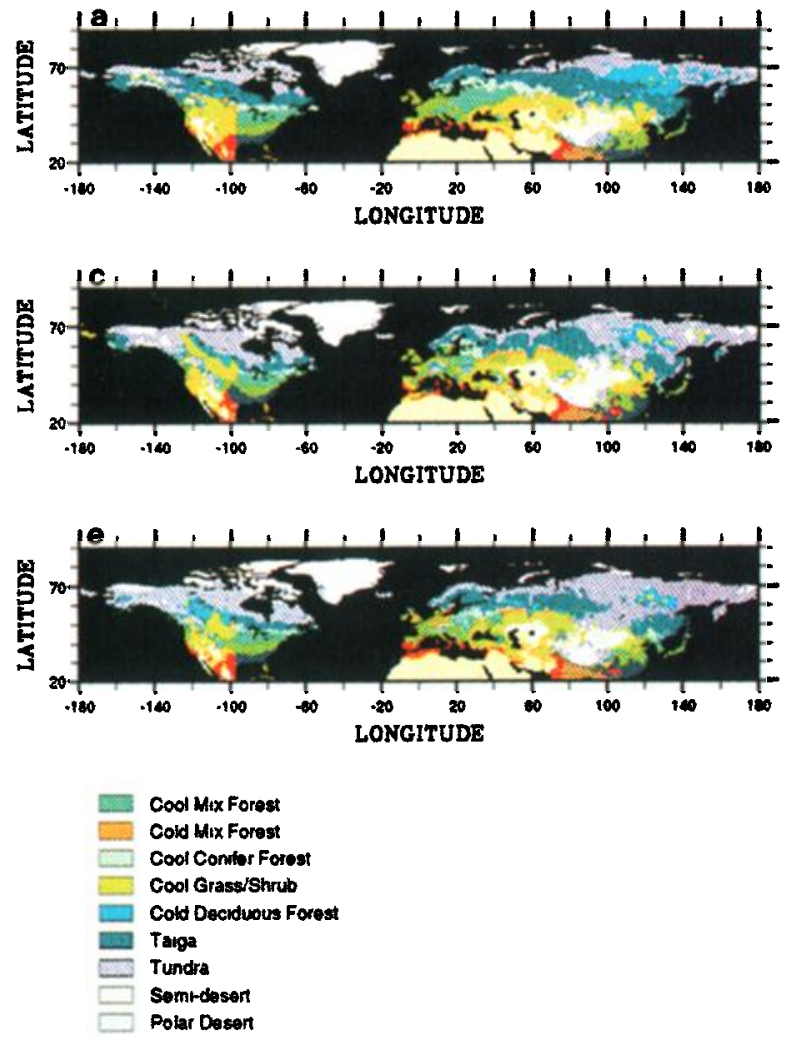

Figure 4. Simulated vegetation distribution $\left(20-90^{\circ} \mathrm{N}\right): a$, present, based on climatological data [Leemans and Cramer, 1991]; b, from experiment G1, based on $115 \mathrm{kyr}$ BP orbital conditions and present vegetation; $c$, from experiment $\mathrm{G} 2$, based on $115 \mathrm{kyr}$ BP orbital conditions and vegetation from $\mathrm{G} 1 ; d$, from experiment $\mathrm{G} 3$, based on $115 \mathrm{kyr} \mathrm{BP}$ orbital conditions and vegetation from $\mathrm{G} 2$; $e$, from experiment $\mathrm{G} 4$, based on $115 \mathrm{kyr}$ BP orbital conditions and vegetation from G3; $f$, from experiment G5, based on 115 kyr BP orbital conditions and vegetation from G4.

spatial distribution of snow cover (Figure 3 ) varied more between iterations, due to the strength of advective effects [Harrison et al., 1992]. In western Canada, for example, although the tundra area increased steadily (Figure 4), nondirectional changes in the meridional position of the Aleutian Low induced variability in the snow statistics (Figure 3). Certain areas nevertheless showed a consistent trend towards greater snow accumulation (as shown for eastern Canada in Figures $2 b$ and 3): Québec/Labrador, central Canada, Greenland and the Canadian Arctic, northern/western Fennoscandia, northern Siberia and Tibet (Figure 3). The high-relief areas of Labrador and the Canadian Arctic (e.g. Baffin Island) and the mountains of Fennoscandia have been considered as likely initial growth centres for the Laurentide and Fennoscandian ice sheets, respectively [Ives et al., 1975; Andrews and Mahaffy, 1976]. Thus, our results point to a mechanism by which biogeophysical feedback could have helped to create conditions favourable to the growth of mid-latitude ice sheets.

\section{Discussion}

There can be many reasons why most AGCMs do not initiate glaciation when sea-surface temperature and sea-ice distribution are kept as present, see Dong and Valdes [1995] and Phillipps and Held [1994]. One of them is the present-day land-surface temperatures simulated in spring and summer. Our control values are about $5^{\circ} \mathrm{C}$ too warm in the mid and high northern latitudes. The cooling we simulate may be correct, but the ground is still too warm in the model to prevent snow from melting. Another possible problem is in the snowmelt parameterization. Oglesby [1990] and Dong and Valdes [1995] showed that if all the available excess energy is applied to
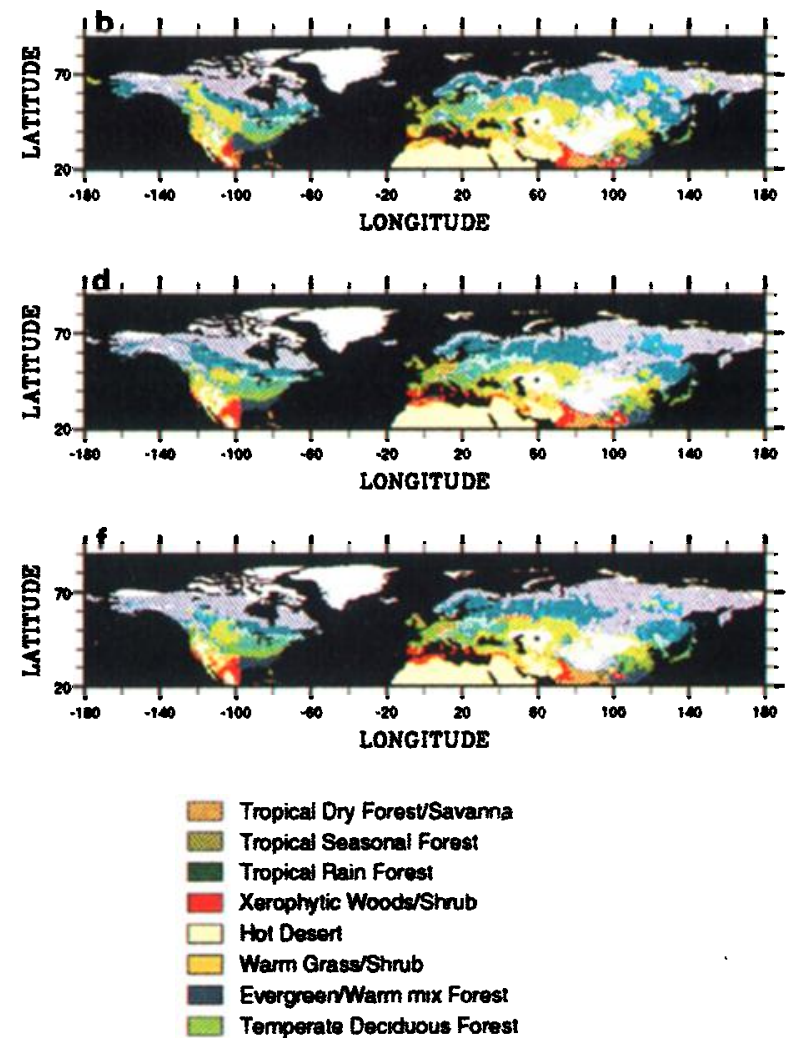

snowmelt, as in our AGCM and many others, then the snow melts too quickly.

Our simulations cannot give a complete picture of the climatic conditions around the end of stage 5e. Changes in the thermohaline circulation may also have contributed to the start of glaciation [Imbrie et al., 1992, 1993]. However substantial cooling in the North Atlantic did not occur until the ice sheets were well developed [Ruddiman and McIntyre, 1979; Cortijo et al., 1994]. A persistently warm sea-surface favoured the delivery of moisture to the growing ice-sheets.

Models that include interactive sea-surface conditions have shown that the low mean annual insolation in high latitudes at 115 kyr BP would have led to increased Arctic sea ice thickness and duration and thus to lower temperatures and greater snow persistence on the northern continents [Phillipps and Held, 1994; Syktus et al., 1994; Harrison et al., 1995; Gallimore and Kutzbach, 1995; Dong and Valdes, 1995]. Moreover, vegetation-induced spring and summer cooling might have been amplified by the biosphere-atmosphere-ocean interaction mechanism [Bonan et al., 1992; Foley et al., 1994; Gallimore and Kutzbach, 1996].

Our results support the hypothesis [Gallée et al., 1992] that consideration of biosphere-atmosphere interactions, which may be further modified by atmosphere-ocean interactions, is essential for understanding and modelling the dynamics of glacial-interglacial cycles. These interactions can only be fully explored by explicit interactive coupling of models of the atmosphere and biosphere.

Acknowledgements. This work was supported by the Commissariat à l'Energie Atomique (CEA), the Programme National d'Etude de la 
Dynamique du Climat (PNEDC), the Environment Programme of the European Union (EEC contract $N^{\circ}$ EV5V-CT92-0118), and the Swedish Natural Science Research Council (NFR). It is a contribution to the core research of the IGBP Global Change and Terrestrial Ecosystems (GCTE) project. We thank Martin Claussen, Sandy Harrison and Pascale Braconnot for discussions.

\section{References}

Andrews, J.T., and M.A.W. Mahaffy, Growth rates of the Laurentide ice sheet and sea level lowering (with emphasis on the 115,000 B.P. sea level low), Quat. Res., 6, 167-183, 1976.

Barnola, J.M., D. Raynaud, D. Korotkevich, and C. Lorius, Vostok ice core provides 160,000 -year record of atmospheric $\mathrm{CO}_{2}$, Nature, 329, 408-413, 1987.

Berger, A., Milankovitch theory and climate, Rev. Geophys., 26, 624$657,1988$.

Berger, A., and M.F. Loutre, Insolation values for the climate of the last 10 million years, Quat. Sci. Rev., 10, 297-317, 1991.

Bonan, G.B., D. Pollard, and S.L. Thompson, Effects of boreal forest vegetation on global climate, Nature, 359, 716-718, 1992.

Chalita, S., and $\mathrm{H}$. le Treut, The albedo of temperate and boreal forest and the northern hemisphere climate: a sensitivity experiment using the LMD AGCM, Clim. Dyn., 10, 231-240, 1994.

Claussen, M., On coupling global biome models with climate models, Climate Research, 4, 203-221, 1994.

Cortijo, E., J.C. Duplessy, L. Labeyrie, H. Leclaire, J. Duprat, and T.C.E. van Weering, Eemian cooling in the Norwegian sea and North Atlantic ocean preceding continental ice-shet growth, Nature, 372, 446-449, 1994.

Dong, B., and P. Valdes, The sensitivity studies of northern hemisphere glaciation using an atmospheric general circulation model, J. Clim., 8, 2471-2496, 1995.

Ducoudre, N., K. Laval, and A. Perrier, SECHIBA, a new set of parameterizations of the hydrologic exchanges at the land-atmosphere interface within the LMD atmospheric general circulation model, J. Clim., 6, 248-273, 1993.

Foley, J.A., J.E. Kutzbach, M.T. Coe, and S. Levis, Feedbacks between climate and boreal forests during the Holocene epoch, Nature, 371, 52-54, 1994.

Gallée J-F., van Ypersele J.P., Fichefet T., Marsiat I., Tricot C., and Berger A., Simulation of the last glacial cycle by a coupled, sectorially averaged climate-ice sheet model. Part 2: Response to insolation and $\mathrm{CO}_{2}$ variations, J. Geophys. Res., 97 (DI4), 15713 15740, 1992.

Gallimore, R.G., and J.E. Kutzbach. Snow cover and sea ice sensitivity to generic changes in Earth orbital parameters, J. Geophys. Res., 100, 1103-1120, 1995.

Gallimore, R.G., and J.E. Kutzbach, Role of orbitally induced changes in tundra area in the onset of glaciation, Nature, 381, 503-505, 1996.

Harrison S.P., J.E. Kutzbach, I.C. Prentice, P.J. Behling, and M.T. Sykes, The response of northern hemisphere extratropical climate and vegetation to orbitally induced changes in insolation during the last interglaciation, Quaternary research, 43 (2), 174-184, 1995.

Harrison, S.P., I.C. Prentice, and P.J. Bartlein, Influence of insolation and glaciation on atmospheric circulation in the North Atlantic sector: implication of general criculation model experiments for the Late Quaternary climatology of Europe, Quat. Sci. Rev., 11, 283-300, 1992.

Harzallah A., and R. Sadourny, Internal versus SST-forced atmospheric variability as simulated by an atmospheric general circulation model, J. Clim., 8, 474-495, 1995.

Haxeltine, A., I.C. Prentice, BIOME3: An equilibrium terrestrial biosphere model based on ecophysiological constraints, resource availability and competition among plant functional types, Global Biogeochemical Cycles, in press.

Hays, J.D., J. Imbrie, and N.J. Shackleton, Variations in the earth's orbit: pacemaker of the ice ages, Science, 194, 1121-1132, 1976.

Henderson-Sellers, A., Continental vegetation as a dynamic component of a global climate model: a preliminary assessment, Climatic Change, 23, 337-377, 1993.

Hewitt, C.D., and J.F.B. Mitchell, GCM simulations of the climate of 6kBP: mean changes and inter-decadal variability, J. Clim., in press.
Imbrie, J., et al., On the structure and origin of major glaciation cycles. 1. Linear respobses to Milankovitch forcing, Paleoceanography, 7, 701738, 1992.

Imbrie, J., et al., On the structure and origin of major glaciation cycles. 2. The 100,000-year cycle, Paleoceanography, 8, 699-735, 1993.

Ives, J.D., J.T. Andrews, and R.G. Barry, Growth and decay of the Laurentide ice sheet and comparison with Fenno-Scandinavia, Naturwissenschaften, 62, 118-125, 1975.

Jolly, D., S.P. Harrison, B. Damnati, and R. Bonnefille, Simulated climate and biomes of Africa during the Late Quaternary: comparison with pollen and lake status data, Quat. Sci. Rev., in press.

Joussaume, S., and K. Taylor, Status of the Paleoclimate Modeling Intercomparsion Project (PMIP), Proc. AMIP conf. (WCRP), 1995.

Leemans, R., and W. Cramer, The IIASA climate database for mean monthly values of temperature, precipitation and cloudiness on a terrestrial grid, IIASA Res. Rep., RR-91-18, 1991.

Oglesby, R.J., Sensitivity of glaciation to initial snow cover, $\mathrm{CO}_{2}$, snow albedo, and oceanic roughness in the NCAR CCM, Clim. Dyn., 4, 219235, 1990.

Phillipps, P.J., and I.M. Held, The response to orbital perturbations in an atmospheric model coupled to a slab ocean, J. Clim., 7, 767-782, 1994.

Prentice, I.C., W. Cramer, S.P. Harrison, R. Leemans, R.A. Monserud, and A.M. Solomon, A global biome model based on plant physiology and dominance, soil properties and climate, J. Biogeography., 19, 117-134, 1992.

Rind, D, D. Peteet, and G. Kukla, Can Milankovitch orbital variations initiate the growth of ice sheets in a general circulation model?, $J$. Geophys. Res., 94 (D10), 12 851-12 871, 1989.

Royer J.F., Deque M., and Pestiaux P.A., Sensitivity experiment of astronomical forcing with a spectral GCM: simulation of the annual cycle at $125000 \mathrm{BP}$ and $115000 \mathrm{BP}$, in Milankovitch and Climate, edited by A.L. Berger et al., 2, 73-763, NATO ASI series, Reidel Publ. Co., 1984.

Ruddiman, and McIntyre, Warmth of the subpolar North Atlantic during the Northern hemisphere ice-sheet growth, Science, 204, 173-175, 1979.

Sadourny R., and K. Laval, January and July performance of the LMD general circulation model, in New Perspectives in Climate Modelling, 173-198, Elsevier, Amsterdam, 1984.

Street-Perrott F.A., Mitchell J.F.B., Marchand D.S., and Brunner J.S., Milankovitch and albedo forcing of the tropical monsoons: a comparison of geological evidence and numerical simulations for 9000 yBP, Transactions of the Royal Society of Edinburgh: Earth Sciences, 81, 407-427, 1990.

Syktus, J., H. Gordon, and J. Chappell, Sensitivity of a coupled atmosphere-dynamic upper ocean GCM to variations of $\mathrm{CO}_{2}$, solar constant, and orbital forcing, Geoph. Res. Lett., 21, 1599-1602, 1994.

TEMPO Members, The potential role of vegetation feedback in the climate sensitivity of high latitude regions: a case study at 6000 years before present, Global Biogeochemical Cycles, in press.

N. de Noblet, Laboratoire de Modélisation du Climat et de l'Environnement, DSM, Orme des Merisiers - Bât. 709, C.E. Saclay, 91191 Gif-sur-Yvette cedex, France. (e-mail: noblet@asterix.saclay.cea.fr)

C. Prentice, Global Systems Group, Department of Ecology, Lund University, Ecology Building, Sölvegatan 37, S-22362 Lund, Sweden. (email: colin@planteco.lu.se)

S.Joussaume, Laboratoire de Modélisation du Climat et de l'Environnement, DSM, Orme des Merisiers - Bât. 709, C.E. Saclay, 91191 Gif-sur-Yvette cedex, France. (e-mail: syljous@asterix.saclay.cea.fr)

D. Texier, Laboratoire de Modélisation du Climat et de l'Environnement, DSM, Orme des Merisiers - Bât. 709, C.E. Saclay, 91191 Gif-sur-Yvette cedex, France. (e-mail: dauphin@asterix.saclay.cea.fr)

A. Botta, Laboratoire de Modélisation du Climat et de l'Environnement, DSM, Orme des Merisiers - Bât. 709, C.E. Saclay, 91191 Gifsur-Yvette cedex, France. (e-mail: botta@asterix.saclay.cea.fr)

A. Haxeltine, Global Systems Group, Department of Ecology, Lund University, Ecology Building, Sölvegatan 37, S-22362 Lund, Sweden. (email: alex.haxeltine@planteco.lu.se)

(Received July 1, 1996; accepted September 23, 1996.) 